\title{
Principal Components \& Classification Analysis - Tool for Festuca rupicola Biodynamic Estimation Depending on Grassland Fertilisation
}

\author{
Monica HARMANESCU**, Veronica SARATEANU \\ Faculty of Agriculture. Banat's University of Agricultural Sciences and Veterinary Medicine "Regele \\ Mihai I al Romaniei" from Timisoara, Calea Aradului, no.119, PC 300645, Romania. \\ * corresponding authors: monica.harmanescu@yahoo.com
}

Bulletin UASVM series Agriculture 73(2)/2016

Print ISSN 1843-5246; Electronic ISSN 1843-5386

DOI 10.15835/buasvmcn-agr: 12411

\begin{abstract}
The grassland forage must be monitored related to the quantitative and qualitative parameters. Festuca rupicola is one of the grass desired in grassland forage. It is necessary to have accessible statistical tools to monitor the Festuca rupicola biodynamic. The objective of the present research was to study that multivariate analysis technique Principal Components \& Classification Analysis (PC\&CA) can be used as a statistical tool for the estimation of Festuca rupicola biodynamic dependent of the fertilisation. The experimental results for Festuca rupicola cutting were collected in June and August 2009 from a hill permanent grassland ecosystem, with a substances flow anthropic influenced by application of mineral and organic (sheep manure) fertilisers. The hill permanent grassland was situated in Banat, Romania, on a Calcic Luvisol. It was selected eight trials as PC\&CA cases, the Festuca rupicola biodynamic data as supplementary variables, and as active variables the fertilisation data and ecological soil parameters. The correlation coefficients of Festuca rupicola biodynamic parameters (Fr1 and Fr2) were positively in mineral fertilisation case and negatively for sheep manure application. The Festuca rupicola biodynamic in June 2009 was high positive correlated with the Festuca rupicola biodynamic in August 2009 (0.835). The statistical data performed in the present study have shown that the multivariate analysis technique PC\&CA can be used as a statistical tool for the estimation of Festuca rupicola biodynamic dependent of the mineral and/or organic fertilisation of hill grassland ecosystem.
\end{abstract}

Keywords: ecosystem, fertilisation, forage, grass, multivariate analysis.

\section{INTRODUCTION}

The forage from permanent grassland represents also in Romania the cheapest feed (Moisuc and Dukic, 2002) relating to the cost of the productive value of animal. According with Marusca et al. (2010), the grassland forage can assure the feed for $60 \%$ of cattle and $80 \%$ of sheep in our country. For maximize the animal production is of foremost importance to monitor the quantitative and qualitative parameters of grassland forage. The floristic composition of grassland covering biomass is one of the determinant parameter which influence the forage quality and quantity. The grassland plants production can be influence anthropic by the amendments and fertilisers (mineral and/or organic) application (Dragomir, 2005; Iacob et al., 2000; Rotar and Carlier, 2010; Van Dijk et al., 2015), because of the necessities of available inputs vs. outputs equilibrium requirements assurance also for permanent grassland ecosystem.

Festuca rupicola is a desired grass in the forage of grassland spontaneous flora. The stimulation of native perennial Festuca rupicola biodynamic in permanent grassland ecosystem must be an objective for farmers. To monitor the Festuca rupicola biodynamic it is necessary to have simple and accessible statistical tools. Multivariate analysis technique was used more and more in the last years to monitor in the 
same time a large number of qualitative and quantitative parameters for plants (Abdur Rahim et al., 2008; Arceusz and Wesolowski, 2015; Chun et al., 2007; Gader et al., 2014; Sinha and Mishra, 2013), even for grassland forage (Poetsch et al., 2014; Scotton et al., 2005). The present research was conducted to use the multivariate analysis technique PC\&CA as a statistical tool in case of Festuca rupicola biodynamic estimation dependent of the fertilisation of a hill permanent grassland ecosystem.

\section{MATERIALS AND METHODS}

\section{Festuca rupicola harvesting}

The Festuca rupicola samples were cut in 2009 from a permanent grassland situated in a hill region of Romania, in two steps: first time in June, and the second time in August. The percent of this grass individual participation in the grassland covering biomass was determinate gravimetrically.

\section{Soil and climatic conditions of}

\section{experimental field}

The hill permanent grassland, chosen as experimental field for Festuca rupicola biodynamic study, was situated in Caras-Severin district, near Gradinari village $\left(45^{\circ} 12^{\prime} \mathrm{N} ; 21^{\circ} 60^{\prime} \mathrm{E}\right)$, and was for the first time fertilised in 2003, mineral yearly (NPK complex, ammonium nitrate, superphosphate, and potassium salt) and organic at each two years (fermented sheep manure).

Calcic Luvisol was the experimental field soil. Humus content was estimated using Walklay - Black - Gogoaşă method, and the available phosphorus and potassium (mobile form) from soil were quantified by Egner-Riehm-Domingo method: extraction with ammonium acetatelactate solution at $\mathrm{pH}=3.7$ (Stoica et al., 1986). The soil hydrolysis pH (SR ISO 10390/1999) of hill permanent grassland trials in studied period varied between 5.43 - 6.00, more acidified in exclusive mineral fertilisation cases.

The clime is temperate continental with Mediterranean influences (Ianoș, 2005). The average temperature during April to June 2009 increased from $14.5^{\circ} \mathrm{C}$ to $19.5^{\circ} \mathrm{C}$. In July 2009 the average temperature was around $22^{\circ} \mathrm{C}$, and in August $22.4^{\circ} \mathrm{C}$. The rainfall during the period April - June 2009 increased from $31 \mathrm{~mm}$ to $166 \mathrm{~mm}$. In July 2009 the rainfall was around $133 \mathrm{~mm}$, and in August 2009 around $55 \mathrm{~mm}$. The climatic data were purchased from the Meteorological Station
Archive, Oravita, Caras-Severin district.

\section{Experimental field design}

The design for the experimental trials was the complete randomised block with 5 replications. Each trial had $25 \mathrm{~m}^{2}$. Festuca rupicola grass was cut at $3 \mathrm{~cm}$ height above soil, from $1 \mathrm{~m}^{2}$ surface of each experimental trials from the hill permanent grassland: unfertilised trial - A; organic fertilised trials: B, C, D with 20t/ha, 40t/ha and respectively $60 \mathrm{t} /$ ha sheep manure; organic-mineral fertilised trial: $\mathbf{E}$ with $20 \mathrm{t} / \mathrm{ha}$ sheep manure $+50 \mathrm{P}_{2} \mathrm{O}_{5}(\mathrm{~kg} /$ ha) $+50 \mathrm{~K}_{2} \mathrm{O}(\mathrm{kg} / \mathrm{ha})+50 \mathrm{~N}(\mathrm{~kg} / \mathrm{ha}) ;$ mineral fertilised trials: $\mathbf{F}-100 \mathrm{~N}(\mathrm{~kg} / \mathrm{ha})+50 \mathrm{P}_{2} \mathrm{O}_{5}(\mathrm{~kg} / \mathrm{ha})$ $+50 \mathrm{~K} 2 \mathrm{O}(\mathrm{kg} / \mathrm{ha}) ; \mathbf{G}-150 \mathrm{~N}(\mathrm{~kg} / \mathrm{ha})+50 \mathrm{P}_{2} \mathrm{O}_{5}(\mathrm{~kg} /$ ha) $+50 \mathrm{~K}_{2} \mathrm{O}(\mathrm{kg} / \mathrm{ha}) ; \quad \mathrm{H}-(100+100) \mathrm{N}(\mathrm{kg} / \mathrm{ha})+$ $50 \mathrm{P}_{2} \mathrm{O}_{5}(\mathrm{~kg} / \mathrm{ha})+50 \mathrm{~K}_{2} \mathrm{O}(\mathrm{kg} / \mathrm{ha})$.

Statistical analysis of the experimental results

The obtained resultswerestatistically analysed using multivariate analysis technique Principal Components \& Classification Analysis (PC\&CA), with the help of StatSoft - STATISTICA VERSION 10. The number of selected cases were eight. The active variables depended on the fertilisers applications doses, and the humus, available phosphorus and potassium (mobile form) of the soil samples from hill permanent grassland. The supplementary variables were the two samples sets of Festuca rupicola individual participation in grassland biomass (gravimetrically determinate), harvested in June and August 2009. The results were performed via the correlation matrix.

\section{RESULTS AND DISCUSSION}

The Festuca rupicola biodynamic in the hill permanent grassland ecosystem, influenced anthropic by mineral and/or organic (sheep manure) fertilisation, was studied for two different periods in 2009.

For the first harvesting period (June), the obtained results for Festuca rupicola gravimetric percent of grassland covering biomass was: A-42\%, B-28\%, C-22\%, D-16\%, E-52\%, F-51\%, G-46\% and $\mathbf{H}-43 \%$. In August 2009 the gravimetric percent of grassland covering biomass by Festuca rupicola was: A-22\%, B-25\%, C-15\%, D-22\%, E-36\%, F-40\%, G-34\% and $\mathbf{H}-31 \%$. Both sets of plant cutting results were used as supplementary variables for study the Festuca rupicola biodynamic depending on fertilisation by PC\&CA. 
The active variables of multivariate analysis technique PC\&CA had the role to characterise the trials ecologic conditions of grassland ecosystem depending on fertilisation doses, mineral and/or organic (sheep manure).

The humus content $(0-10 \mathrm{~cm}$ deep) of the hill grassland trials for unfertilised case $\mathbf{A}$ was $6.18 \%$.

For organic fertilised trials the humus content increased with the increasing of sheep manure doses: B-6.44\%, C-7.62\% and D-9.04\%. The organic-mineral fertilised trial (E) soil had 9.03\% humus, while the mineral fertilised trials had $7.28 \%$ (F), 6.19\% (G), respectively $8.05 \%$ (H).

Another active variable used to compute the PC\&CA for Festuca rupicola biodynamic depending on fertilisation was the available phosphorus content $(0-10 \mathrm{~cm}$ deep), mobile form, for the soil of each 8 selected experimental grassland trials: A-43.88 ppm, B-47.65 ppm, C-53.93 ppm, D-71.53 ppm, E-69.70 ppm, F-54.78 ppm, G-50.55 ppm and $\mathbf{H}-52.70 \mathrm{ppm}$. The available potassium content (0-10 $\mathrm{cm}$ deep), mobile form, for the soil of each 8 selected grassland trials, was:
A-229 ppm, B-233 ppm, C-230 ppm, D-236 ppm, E-251 ppm, F-238 ppm, G-224 ppm and $\mathbf{H}-232$ ppm.

The multivariate analysis technique PC\&CA was used to analyse the Festuca rupicola biodynamic depending on grassland fertilisation and 6 principal components were obtained, describing a quality of representation of $100 \%$. The Eigenvalues of the correlation matrix are presented in Fig. 1.

The first principal component (PC1) had the Eigenvalue 3.319 and explained $47.42 \%$ of total variance.

The second principal component (PC2) had the Eigenvalue 2.930 and explained $41.857 \%$ of total variance. It is obviously that PC1 and PC2 explain more than $89 \%$ of total variance. The third and the fourth principal components had the Eigenvalues 0.577, respectively 0.132, and described only $8.24 \%$, respectively $1.89 \%$ of total variance.

The correlations of principal components PC1 and PC2 vs. variables (factor loadings) of PC\&CA

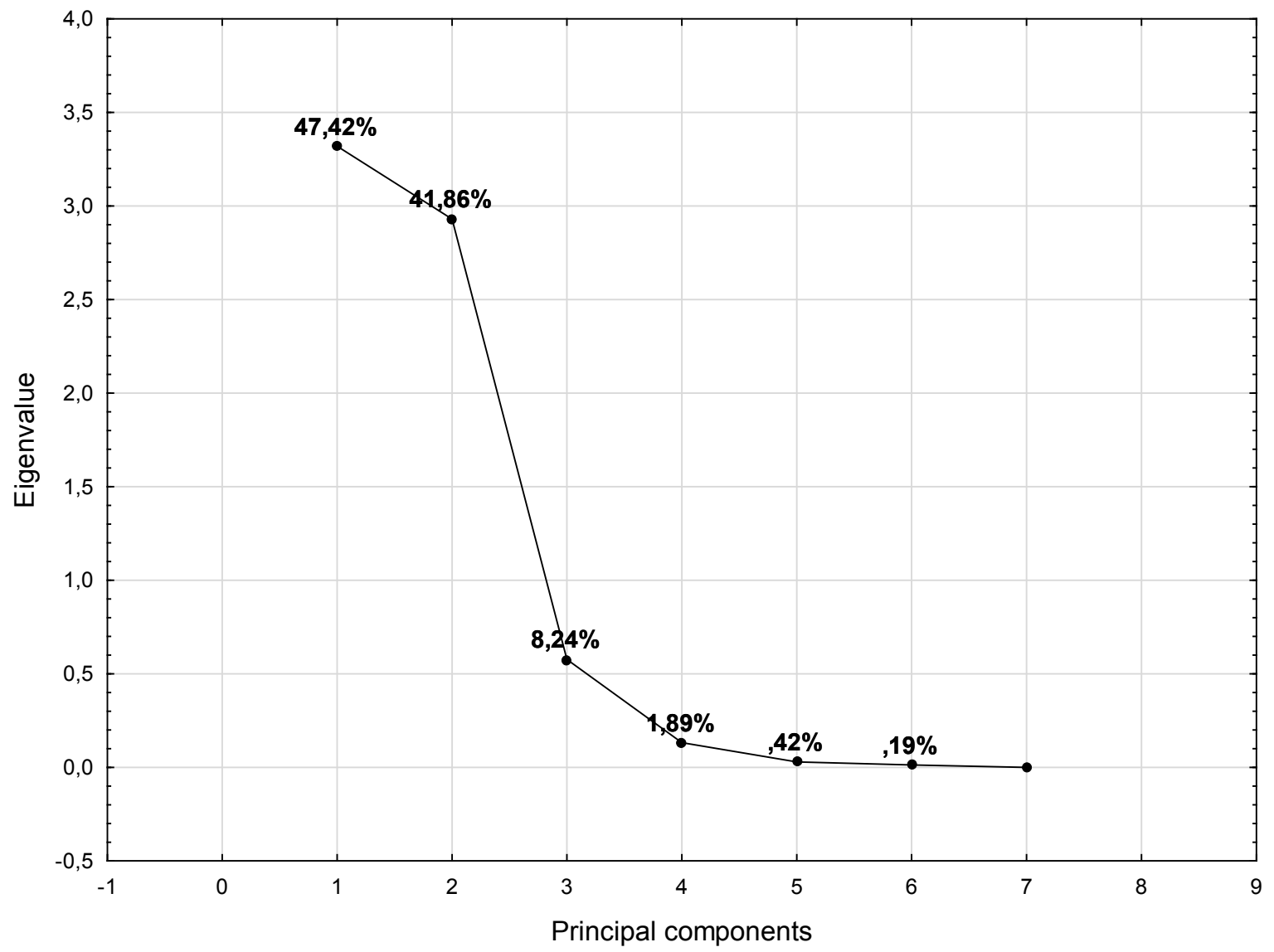

Fig. 1. The Eigenvalues of the correlation matrix 
Tab. 1. The correlations of PC1 and PC2 vs. variables (factor loadings) of PC\&CA

\begin{tabular}{lcc}
\hline Variables & Principal component 1 & Principal component 2 \\
\hline Manure (t/ha) & 0.872 & -0.329 \\
\hline $\mathrm{N}(\mathrm{kg} / \mathrm{ha})$ & -0.902 & -0.164 \\
\hline $\mathrm{P}(\mathrm{kg} / \mathrm{ha})$ & -0.873 & -0.474 \\
\hline $\mathrm{K}(\mathrm{kg} / \mathrm{ha})$ & -0.873 & -0.474 \\
\hline Humus $(\%)$ & 0.300 & -0.910 \\
\hline P mobile form (ppm) & 0.342 & -0.909 \\
\hline $\mathrm{K}$ mobile form (ppm) & 0.125 & -0.832 \\
\hline${ }^{*}$ Fr1 (\%) & $\mathbf{- 0 . 8 3 5}$ & $\mathbf{- 0 . 1 7 5}$ \\
\hline${ }^{*}$ Fr2 (\%) & $\mathbf{- 0 . 7 7 1}$ & $\mathbf{- 0 . 4 3 4}$ \\
\hline
\end{tabular}

Note: Fr1 - Festuca rupicola biodynamic in June 2009; Fr2 - Festuca rupicola biodynamic in August 2009.

are presented in Tab. 1 .

First cases group of multivariate analysis technique PC\&CA contained the unfertilised trial $\mathbf{A}$ and the trials fertilised exclusively with sheep manure $\mathbf{B}(20 \mathrm{t} / \mathrm{ha})$ and $\mathbf{C}(40 \mathrm{t} / \mathrm{ha})$. The second cases group included the exclusively organic fertilised trial $\mathbf{D}$, with the highest doses of sheep manure (60 t/ha).

The third cases group classified the organicmineral fertilised trial $\mathbf{E}$, with the minimum sheep manure (20 t/ha), $50 \mathrm{~kg} / \mathrm{ha} \mathrm{P}_{2} \mathrm{O}_{5}, 50 \mathrm{~kg} / \mathrm{ha} \mathrm{K}_{2} \mathrm{O}$ and the minimum mineral nitrogen doses $(50 \mathrm{~kg} /$ ha).

Last cases group, the fourth, included only exclusive mineral fertilised trials $\mathbf{F}, \mathbf{G}$ and $\mathbf{H}$, with a constant dose of $50 \mathrm{~kg} /$ ha $\mathrm{P}_{2} \mathrm{O}_{5}$, respectively $\mathrm{K}_{2} \mathrm{O}$, and different mineral nitrogen doses: 100, 150, $(100+100) \mathrm{kg} / \mathrm{ha}$.

The PC1 of multivariate analysis technique PC\&CA for Festuca rupicola biodynamic depending

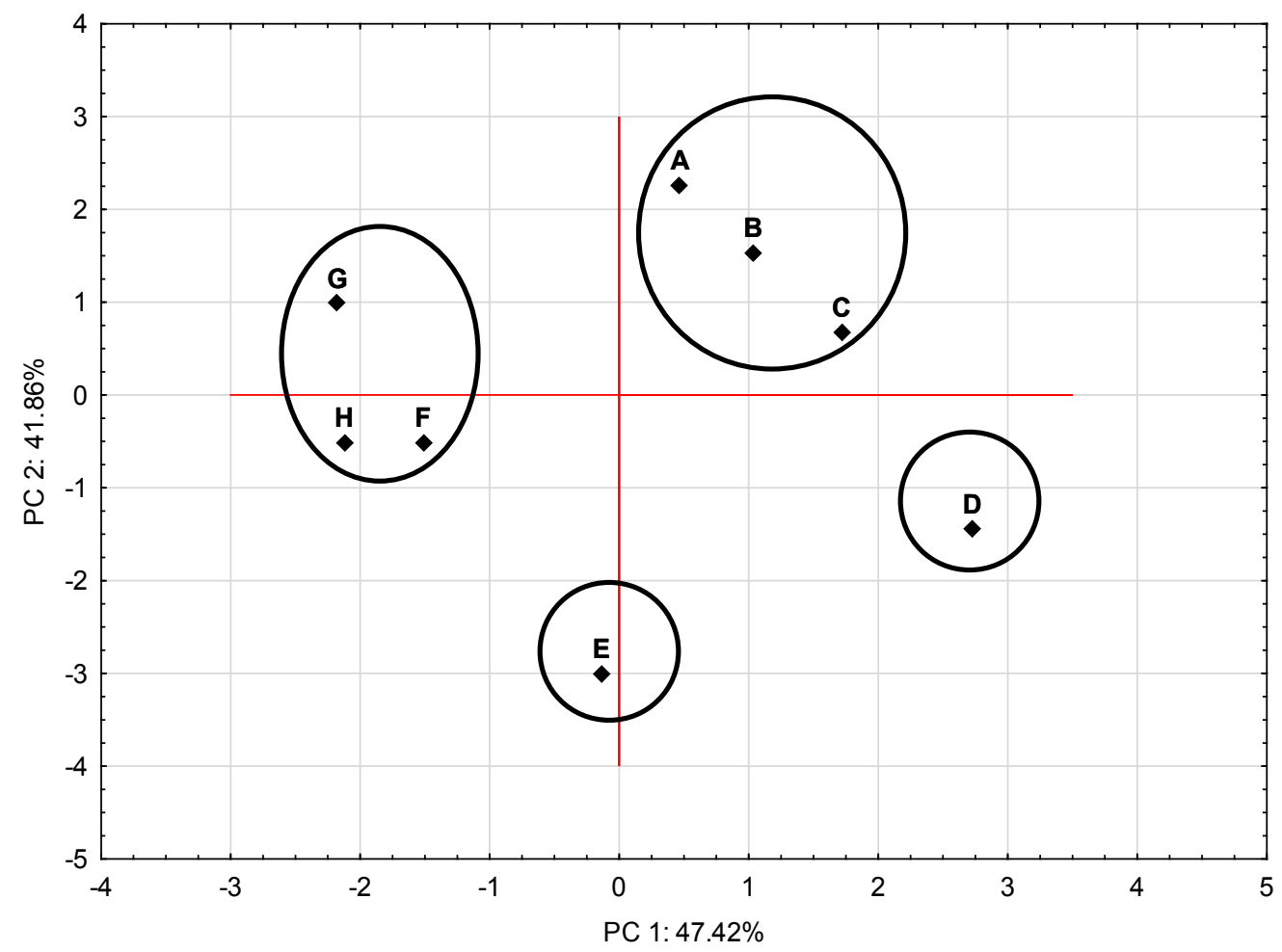

Fig. 2. Projection of the 8 cases of hill permanent grassland fertilisation on PC1xPC2 plane 
Tab. 2. The correlation coefficients between the active and supplementary variables of PC\&CA

\begin{tabular}{lcccccccc}
\hline Variables & $\begin{array}{c}\text { Manure } \\
(\mathrm{t} / \mathrm{ha})\end{array}$ & $\begin{array}{c}\mathrm{N} \\
(\mathrm{kg} / \mathrm{ha})\end{array}$ & $\begin{array}{c}\mathrm{P} \\
(\mathrm{kg} / \mathrm{ha})\end{array}$ & $\begin{array}{c}\mathrm{K} \\
(\mathrm{kg} / \mathrm{ha})\end{array}$ & $\begin{array}{c}\text { Humus } \\
(\%)\end{array}$ & $\begin{array}{c}\text { P mobile } \\
\text { form } \\
(\mathrm{ppm})\end{array}$ & $\begin{array}{c}\mathrm{K} \\
\text { mobile } \\
\text { form } \\
(\mathrm{ppm})\end{array}$ & $\begin{array}{c}\text { *Fr1 } \\
\mathbf{( \% )}\end{array}$ \\
\hline${ }^{*}$ Fr1 (\%) & -0.840 & 0.588 & 0.821 & 0.821 & -0.176 & -0.168 & 0.273 & - \\
\hline${ }^{*}$ Fr2 (\%) & -0.597 & 0.648 & 0.899 & 0.899 & 0.053 & 0.143 & 0.399 & $\mathbf{0 . 8 3 5}$ \\
\hline
\end{tabular}

Note: where Fr1 - Festuca rupicola biodynamic in June 2009; Fr2 - Festuca rupicola biodynamic in August 2009.

on fertilisation was generally characterised by the fertilisers influence on hill permanent grassland ecosystem. The organic fertilisation with sheep manure had high positive contribution in PC1 case, while mineral fertilisation with NPK complex, ammonium nitrate, superphosphate, and potassium salt had a high negative contribution. The ecological soil parameters had high negative contribution to characterise the PC2 of PC\&CA.

The projection of the selected 8 cases of hill permanent grassland fertilised trials on the PC1xPC2 plane is presented in Fig. 2.
In the experimental field conditions, characterised by the fertilisation and analysed ecological parameters of grassland soil as active variables for PC1 and PC2, was studied the Festuca rupicola biodynamic in June and August 2009. The projection of the supplementary and active variables on the PC1xPC2 plane is shown in Fig. 3.

The supplementary variable Fr1 indicated that Festuca rupicola biodynamic in June 2009 was influenced positively by mineral fertilisation and negatively by sheep manure application on hill permanent grassland ecosystem.

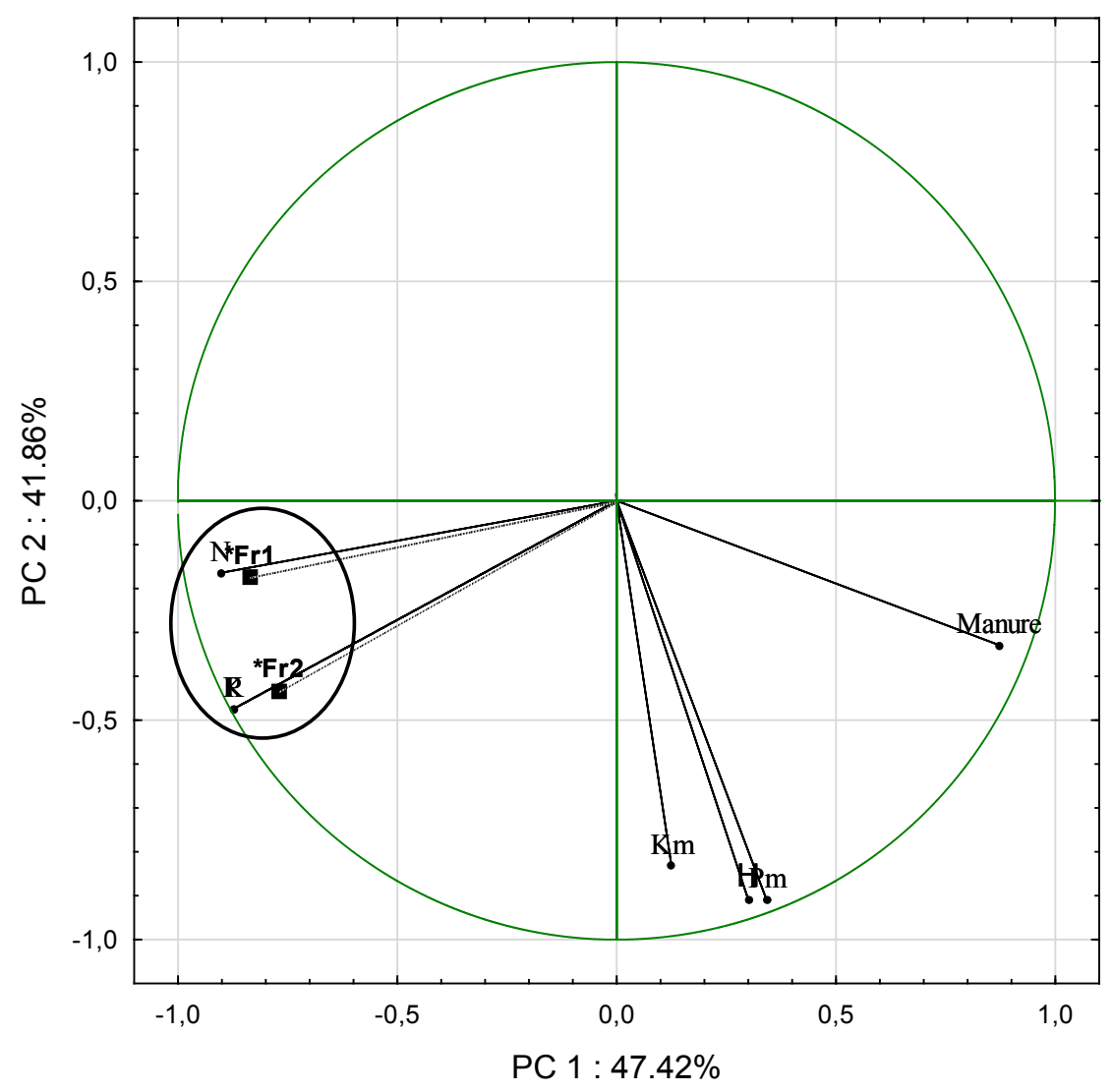

Fig. 3. Projection of the supplementary and active variables on the PC1xPC2 plane 
The same situation was for Fr2 supplementary variable, which described the Festuca rupicola biodynamic in August 2009.

These observations can be analyse also using the correlation coefficients between the active and the supplementary variables of PC\&CA presented in Tab. 2.

The correlation coefficients of Festuca rupicola biodynamic in June 2009 parameter vs Festuca rupicola biodynamic in August 2009 was high positively (0.835). For both studied periods (June and August 2009), the Festuca rupicola biodynamic was stimulated in the hill permanent grassland trials when mineral fertilisers, including mineral nitrogen, were applied, clearly shown by PC\&CA. Fermentd sheep manure applied since 2003, at each two years, on hill permanent grassland, reduced generally the Festuca rupicola participation on biomass covering in soil and clime conditions of Romanian Banat of 2009.

\section{CONCLUSION}

The statistical results obtained in the present research indicate that it is possible to use the multivariate analysis technique Principal Components \& Classification Analysis as a statistical tool for the estimation of Festuca rupicola biodynamic depending on the mineral and/or organic fertilisation. The sheep manure used as organic input in hill permanent grassland ecosystem influenced negatively the biodynamic of Festuca rupicola grass, while mineral fertilisers, including mineral nitrogen, had a positive impact in both studied periods: June and August 2009.

Acknowledgments. All the experimental results used in this study to compute the multivariate analysis technique PC\&CA were obtained for PhD thesis in Agronomy by Harmanescu Monica. On the influence of substances flows on the quality of forage from grassland (2006-2009). Banat's University of Agricultural Sciences and Veterinary Medicine from Timisoara. Romania; coordinator Prof.PhD.Eng. Alexandru Moisuc; with the financial support of a Grant BD/CNCSIS Romania (www. cncsis.ro) 2007 - 2009.

\section{REFERENCES}

1. Abdur RM, Abu AM, Firoz M, Khandker SA (2008). Multivariate Analysis in Some Mungbean (Vigna radiata L. Wilczek) Accessions on the Basis of Agronomic
Traits. American-Eurasian Journal of Scientific Research 3(2):217-221.

2. Arceusz A, Marek W (2015). Essential metals and phenolic acids in commercial herbs and spices. Multivariate analysis of correlations among them. Open Chem 13:1196-1208.

3. Chun YJ, Michael LC, Kirk AM, John DN (2007). Phenotypic Plasticity of Native vs. Invasive Purple Loosestrife: a TwoState Multivariate Approach. Ecology 88(6):1499-1512.

4. Dragomir N (2005). Pajisti si plante furajere. Tehnologii de cultivare. Edited by Eurobit Publisher. Timisoara. Romania.

5. Gader G, Farhad B, Behnam T (2014). The study of important agronomic traits by multivariate analysis in winter rapeseed cultivars. American Journal of Bioscience and Bioengineering 2(1):15-17.

6. Iacob T, Vintu V, Samuil C (2000).Tehnologia producerii si conservarii furajelor. Edited by Ion Ionescu de la Brad Publisher. Iasi. Romania.

7. Ianoş G (2005). Geografia solurilor cu noțiuni generale de pedologie. Edited by Universitatea de Vest. Timişoara.

8. Marusca T, Mocanu V, Cardasol V, Hermenean I, Blaj VA, Oprea G, Tod MA (2010). Ghid de producere ecologica a furajelor de pajisti montane. Edited by Universitatea Transilvania. Brasov. Romania.

9. Moisuc Al, Dukic D (2002). Cultura plantelor furajere. Edited by Orizonturi Universitare Publisher. Timisoara. Romania.

10. Poetsch EM, Asel A, Schaumberger A, Resch R (2014). Impact of climate change on grassland productivity and forage quality in Austria. Grassland Science in Europe Vol.19 - EGF at 50: The Future of European Grasslands:139-141.

11. Rotar I, Carlier L (2010). Cultura pajistilor. Risoprint Publisher. Cluj-Napoca. Romania.

12. Scotton M, Marini L, Sicher L (2005). Relationships between management and diversity of permanent grasslands in the Non Valley (Trentino, NE Italy). Grassland Science in Europe Volume 10 - Integrating Efficient Grassland Farming and Biodiversity:529-532.

13. Sinha AK, Mishra PK (2013). Morphology based multivariate analysis of phenotypic diversity of landraces of rice (Oryza sativa L.) of Bankura district of West Bengal. Journal of Crop and Weed 9(2):115-121.

14. Stoica E coord., Răuță C, Florea N (1986). Metode de analiză chimică a solului. Bucureşti. Romania.

15. Van Dijk H, Schukking S, Van der Berg R (2015). Fifty years of forage supply on dairy farms in the Netherlands. Grassland Science in Europe Vol. 20 - Grassland and forages in high output dairy farming systems:12-20.

16. ***, Meteorological Station Archive, Oravita, Caras-Severin district, for the climatic data.

17. ***, SR ISO 10390 (1999), Calitatea solului. Determinarea pH-ului. 